\title{
RELATIONS BETWEEN STRENGTH AND POWER TESTS AND THE SHORT-DISTANCE SWIMMING SPEED AMONG YOUNG SWIMMERS
}

\author{
Dragan Toskić \\ Faculty of sport and physical education, University of Priština, Leposavić, Serbia
}

\begin{abstract}
Swimming, as a sport where the goal is to be faster, to a great extent depends on the manifestation of strength and power at short distances. An evaluation of dry land strength and power is an important part of the training process, but the evaluation of dry land measurents and its influence on swimming results is problematic, considering the fact that the manifestation of strength and power in the water is specific in comparison to dry land. The aim of this paper is to determine whether there is a correlation between the results of the tests of strength and power from the Eurofit battery test and short-distance swimming speed among young swimmers. The sample of participants consisted of 27 swimmers aged $13 \pm 2.1$ year. The results of Pearson's coefficient and regression analyses indicate that there is a high correlation between the tests of the standing broad jump and the sit-ups with the average swim speed at a distance of $50(\mathrm{r}=0.656, \mathrm{r}=0.833$, respectively) and $100 \mathrm{~m}(\mathrm{r}=0.746, \mathrm{r}=0.640$, respectively), as well as swim time at a distance of $50(\mathrm{r}=-0.623, \mathrm{r}=-0.856$, respectively) and $100 \mathrm{~m}(\mathrm{r}=-0.723$, $r=-0.687$, respectively) freestyle. We can conclude that the standing broad jump and the sit-ups tests of the Eurofit battery tests could be predictors in conclusion about factors of swim speed at short distances among young swimmers, that is, are suitable for the selection of young swimmers.
\end{abstract}

Key words: SWIMMING / MOTORIC ABILITIES / EUROFIT / CHILDREN /

\section{INTRODUCTION}

Strength and power play an important role in most sports, and thus in swimming as well. Swimming, as a sport where the goal is to be faster, to a great extent depends on the manifestation of strength and power (Sharp, Troup, \& Costill, 1982; Garrido et al., 2010; Morouco et al., 2011). This is especially pronounced at short distances, where explosive and maximum strength and power play a decisive role (Hawley \& Williams, 1991; Strzala \& Tyka, 2009; Garrido et al., 2010; Morouco et al., 2011).

An evaluation of dry land strength and power in swimming is an important and constituentpart of the training process (Smith, Norris, \& Hogg, 2002). Data of the manifested strength and power can give insight into whether strength and power training was effective as well as whether the training was focused on those abilities which lead to an increase in swimming performance. Evaluation of dry land strength and power can give insight into the correlation between certain characteristics of strength, power and swim speed, that is, predictive values of certain tests for the evaluation of strength and power, which can play an important role in selection process (Zampagni et al., 2008). However, the evaluation of dry land strength and power and its influence on swimming results isis problematic considering that movement in water is specific in relation to movement on dry land (Swaine, 2000; Smith et al. 2002).

Numerous studies have focused on the correlation between the characteristics of strength and power measured on dry land and performances manifested in water. The result of such a large number of stud- 
ies indicate that there is a high correlation between the characteristics of strength and power measured on dry land and swim speed at short distances, both among older (Sharp et al., 1982; Hawley \& Williams, 1991; Hawley, Williams, Vickovic, \& Handcock, 1992; Bradshaw \& Hoyle, 1993; Gola, Urbanik, Iwanska, \& Madej, 2014; Peters, Berry, \& Koley, 2014; Loturco et al., 2016) and among younger swimmers (Geladas, Nassis, \& Pavlicevic, 2005; Garrido et al., 2010; Morouco et al., 2011; Garrido et al., 2012; Keiner, Yaghobi, Sander, Wirth, \& Hartmann, 2015). However, certain studies negate the correlation between the characteristics of strength and power measured on dry land and swimming performances, which indicates that caution should be taken (Johnson, Sharp, \& Hendrick, 1993; Crowe, Babington, Tanner, \& Stager, 1999; Dominguez-Castelss \& Arrelano, 2011).

The differences among the research results can be ascribed to the test validity and used measuring instruments. As we have already mentioned, swimming is a specific sport, where the manifestation of strength and powerin water significantly differs from the manifestation of dry land strength and power. Thus, not all measuring instruments are suitable for the study of the correlation between dry land strength and power and performances in water. Tests for the evaluation of strength and power in swimming should make sure that movement during task performance does not deviate from specific movement in water (Smith et al., 2002). However, the measuring instruments for this type of evaluation are expensive and are often unavailable to coaches and experts in the field of swimming. This is especially a problem when working with young swimmers. Certain authors indicate that for young swimmers no expensive or complicated or time-consuming equipment is needed to evaluate dry land strength and power (Silva et al., 2007). Also, one of the knowledge drawbacks of previous studies is that most of them were limited to analyzing the strength and power of the muscles of the arms and shoulder belt, even though the muscles of the legs, abdomen and back play an important role in swimming (Deschodt et al., 1999; Toussaint et al., 2006; Keiner et al., 2015).

Very few studies have focused on the correlation between tests of strength and power from the Eurofit battery test and swimming speed. The Eurofit battery of tests is a widely used battery of tests which are sim- ple to use, reliable for the evaluation of motor skills, and the results of these tests can be compared to the results of tests obtained for participants of the same age throughout all of Europe. What is most important is that the battery is available for use and does not require any expensive equipment, which is of great importance, especially for experts who work with children (Oja \& Tuxworth, 1995; Tsigilis, Douda, \& Tokmakidis, 2002; Gajević, 2009).

The subject matter of this research is the evaluation of dry land strength and power among young swimmers. The aim of the paper is to determine whether there is a correlation between the results of the tests for strength and power from the Eurofit battery and swim speed at short distances among young swimmers. Based on the obtained results it can be determined whether the tests for strength and power from the Euroft battery are suitable for the evaluation of the strength and power of young swimmers, that is, whether they can be predictors of swim speed among young swimmers. It is assumed that certain tests will indicate a high correlation with the swim speed of young swimmers.

\section{METHODS}

\section{Participants}

The sample of participants consisted of 27 swimmers, 15 boys and 12 girls (Age: $13 \pm 2.1, \mathrm{BH}=156.1$ $\left.\mathrm{cm}, \mathrm{BW}=47.3 \mathrm{~kg}, \mathrm{BMI}=18.9 \mathrm{~kg} / \mathrm{m}^{2}\right)$. All of the participants were active swimmers, had trained swimming for at least 3 years and actively competed in their age categories. The participants and their parents were familiar with the aim and purpose of the study and had voluntarily agreed to participate in it. All the study procedure were carried out in accordance with the Declaration of Helsinki and the rules of the Ethics Committee of the Faculty of sport and physical education University of Priština.

\section{Sample of variables}

The sample of variables consisted of 4 variables for the evaluation of swimming speed and 3 variables for the evaluation of muscle strength and power. The variables used to evaluate swim speed included (Geladas et al., 2005; Toskić, D., Lilić, \& Toskić, L., 2016): 
- swim time to $50 \mathrm{~m}(\mathrm{t} 50)$

- average swim speed to $50 \mathrm{~m}$ (v50)

- swim time to $100 \mathrm{~m}(\mathrm{t} 100)$

- average swim speed to $100 \mathrm{~m}(v 100)$

Average swim speed is calculated by dividing swimming distance with time that was needed to swim that distance. Swim speed at $50 \mathrm{~m}$ is calculated by taking the covered distance, without the length of the jump, and dividing it by the time needed to swim it, while for the $100 \mathrm{~m}$ sprint the time needed for the turn was also included in the calculation. Swimming tests were recorded with camera and length of the start and turn was determined as a point of the first arm exit on the surface of the water.

The variables for the evaluation of strength and power included:

- standing broad jump (SBJ) - to evaluate the explosive power of the leg muscle extensors

- sit-ups (SUP) - to evaluate the muscular strength and endurance of the abdominal flexors

- bent arm hang (BAH) - to evaluate the muscular endurance and functional strength of the muscles of the arms and the shoulder belt.

The tests for the evaluation of strength and power used in this study were taken from the Eurofit battery of tests (Council of Europe, 1988; Kemper \& Van Mechelen, 1996; Jürimäe, Volbekiene, Jürimäe, \& Tomkinson, 2007). These variables, as well as the Eurofit battery test, were chosen for their availability and simplicity. As previously mentioned, other more precise measuring instruments must be available to evaluate the aforementioned abilities. However, these instruments are often quite expensive and unavailable to swimming coaches who work with children. The selected tests do not require any expensive equipment, are simple to use, valid for the evaluation of certain abilities and the results of these measuring can be compared to the results of other participants of the same age from all of Europe.

\section{The testing procedure}

All of the measurements were taken under the same conditions. The participants were all healthy, rested and all of the tests were carried out in the morning. Prior to the testing, warm up was done so that no injuries would occur and so that they would be able to best express their optimal abilities in water and on dry land. The time and average swim speed were measured in a pool 50 meters in length, while strength and power were measured in additional swimming facilities. The participants swam a distance of $50(\mathrm{t} 50 ; v 50)$ and $100 \mathrm{~m}(\mathrm{t} 100 ; v 100)$ at maximum speed, in two different days. The testing of muscle strength and power was carried out in accordance with the rules and procedures of the Eurofit battery test. The measuring of speed, that is, swim time and the measuring strength and power were carried out on different days so that the participants could be able to rest. All of the measuring were carried out by the same experienced invigilators.

\section{Statistical data analyses}

In this paper we used a descriptive statistical procedure (Mean, SD, cV\%, Min, Max), Pearson's correlation coefficient and linear regression analysis. Descriptive statistics were applied in order to describe the measured variables, while the correlation coefficient and linear regression analysis were used in order to determine the correlation and character of the correlation between the measured variables. The level of statistical significance was calculated at $95 \%$ with $\mathrm{p}<0.05$ (Hair et al., 1998), while all of the statistical procedures were performed using the SPSS 19 program (IBM).

\section{RESULTS}

Table 1 shows the descriptive indicators of swim speed and time for the 50 and $100 \mathrm{~m}$ front-crawl technique as well as the results of the tests of power and strength for the young swimmers. As it can be notised, the participants' average swim time for the 50 $\mathrm{m}$ front-crawl of $36.8 \mathrm{~s}$ and an average swim speed of $1.46 \mathrm{~m} / \mathrm{s}$, while the average swim time for the 100 $\mathrm{m}$ was 85.9 with an average swim speed of $0.56 \mathrm{~m} / \mathrm{s}$. Based on the indicators of the result homogeneity $(\mathrm{cV} \%)$ it can be concluded that the participans were homogenous in the case of this variable. In the case of the tests results for the evaluation of strength and power it can be concluded that the average results for the SBJ was $148.7 \mathrm{~cm}$, the average number of sit-ups 
was 24.1 during 30 seconds, and that the participants had an average result of $16.2 \mathrm{~s}$ in the case of the BAH test. Based on the indicators of the result homogenety it can be concluded that participants are the most ho- mogenous for the SBJ variable $(\mathrm{cV}=12.2 \%)$, while it is the least homogenous for the $\mathrm{BAH}$ variable $(\mathrm{cV}=$ 44. \%).

Table 1. Descriptive indicators of swim time and swim speed for the 50 and $100 \mathrm{~m}$ front-crawl and the tests results for strength and power

\begin{tabular}{cccccccc}
\hline & $\begin{array}{c}\mathbf{5 0} \\
(\mathbf{s})\end{array}$ & $\begin{array}{c}\mathbf{v 5 0} \\
(\mathbf{m} / \mathbf{s})\end{array}$ & $\begin{array}{c}\mathbf{t 1 0 0} \\
(\mathbf{s})\end{array}$ & $\begin{array}{c}\mathbf{v 1 0 0} \\
(\mathbf{m} / \mathbf{s})\end{array}$ & $\begin{array}{c}\text { SBJ } \\
(\mathbf{c m})\end{array}$ & $\begin{array}{c}\text { SUP } \\
(\mathbf{n} / \mathbf{3 0 s})\end{array}$ & $\begin{array}{c}\text { BAH } \\
(\mathbf{s})\end{array}$ \\
\hline Mean & 36.8 & 1.46 & 85.9 & 0.56 & 148.7 & 24.1 & 16.2 \\
SD & 4.02 & 0.18 & 10.5 & 0.08 & 18.1 & 3.1 & 7.2 \\
$\mathbf{c V \%}$ & 10.9 & 12.5 & 12.3 & 14.4 & 12.2 & 12.9 & 44.6 \\
Min & 30.7 & 1.18 & 69.1 & 0.43 & 125.2 & 19 & 8 \\
Max & 43.1 & 1.87 & 101.5 & 0.74 & 186 & 30 & 30.2 \\
\hline
\end{tabular}

Graphs 1 to 8 have indicated statistically significant correlations between the tests results for the evaluation of strength, power and speed, that is, swim time for the 50 and $100 \mathrm{~m}$ front-crawl. It can be concluded that there is a high and statistically significant correlation between the variables SBJ, average swim speed for the $50(\mathrm{r}=0.656, \mathrm{p}=0.000)$ and $100 \mathrm{~m}(\mathrm{r}=$ $0.746, \mathrm{p}=0.000)$ front-crawl as well as swim time for the $50(r=-0.623, p=0.001)$ and $100 \mathrm{~m}(\mathrm{r}=-0.723, \mathrm{p}$

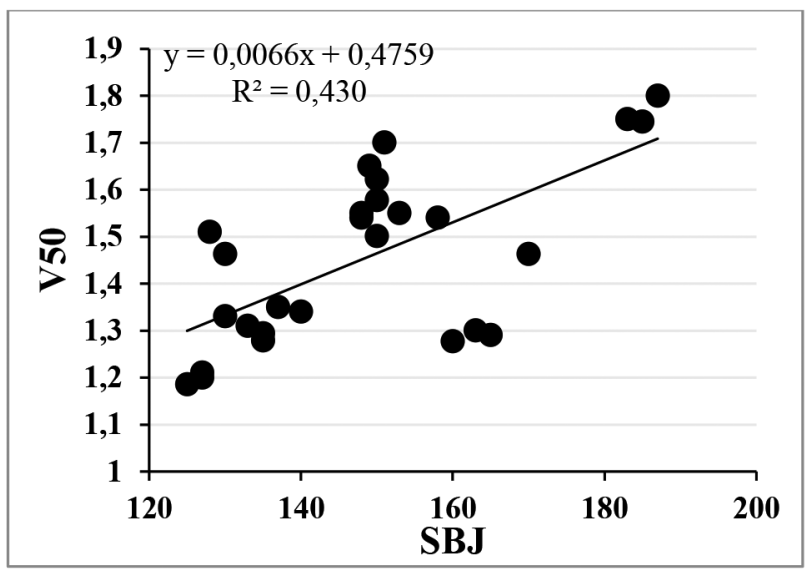

Graph 1. Correlation between the tests results of the SBJ test and swim speed to $50 \mathrm{~m}$
$=0.000)$ front-crawl. The variable SUP has a high and statistically significant connection with swim speed for the $50(\mathrm{r}=0.833, \mathrm{p}=0.000)$ and $100 \mathrm{~m}(\mathrm{r}=0.640$, $\mathrm{p}=0.000)$ front-crawl, as well as swim time for $50(\mathrm{r}$ $=-0.856, \mathrm{p}=0.000)$ and $100 \mathrm{~m}(\mathrm{r}=-0.687, \mathrm{p}=0.000)$ front-crawl. The BAH test is not correlated to the variables used to evaluate swim speed for the 50 and $100 \mathrm{~m}$ front-crawl in a statistically significant way.

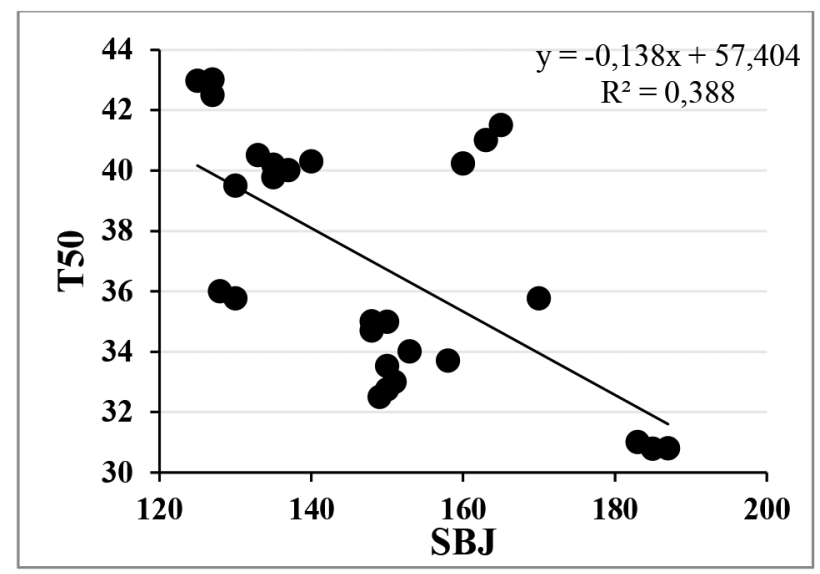

Graph 2. Correlation between the test results of the SUP test and swim time to $50 \mathrm{~m}$ 


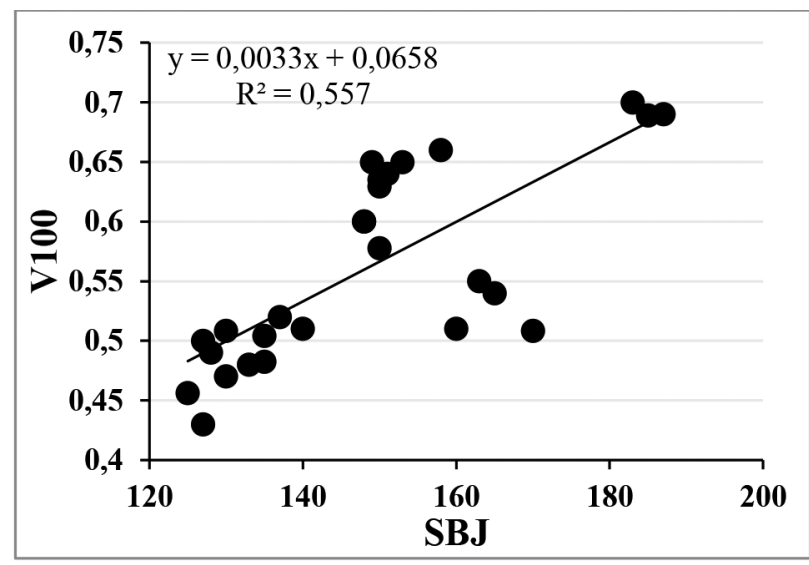

Graph 3. Correlation between the tests results of the SBJ test and swim speed to $100 \mathrm{~m}$

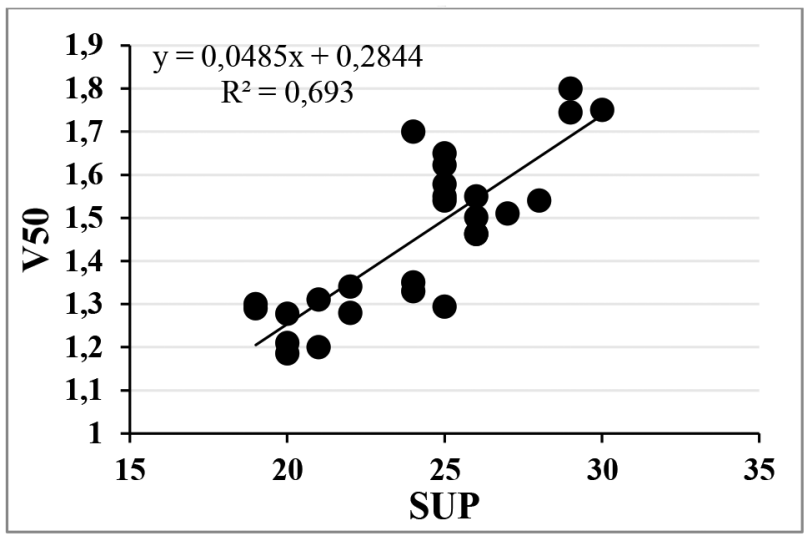

Graph 5. Correlation between the tests results for the SUP test and swim speed to $50 \mathrm{~m}$

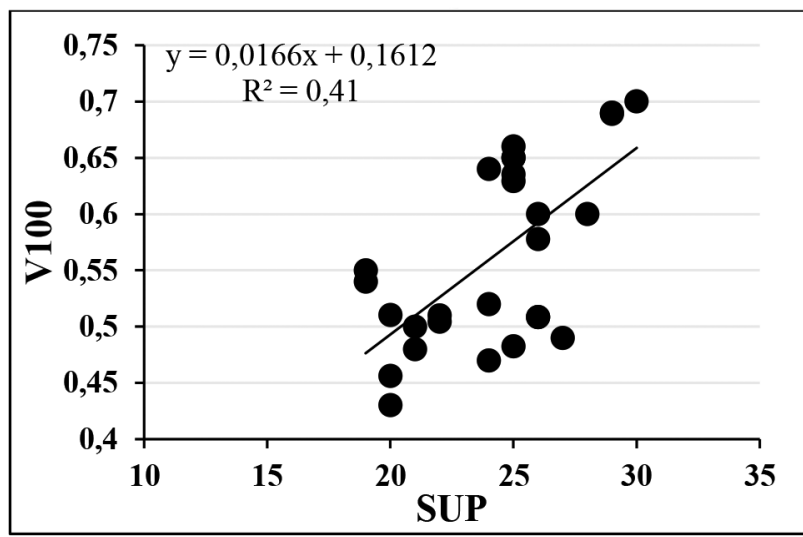

Graph 7. Correlation between the results of the SUP test and swim speed to $100 \mathrm{~m}$

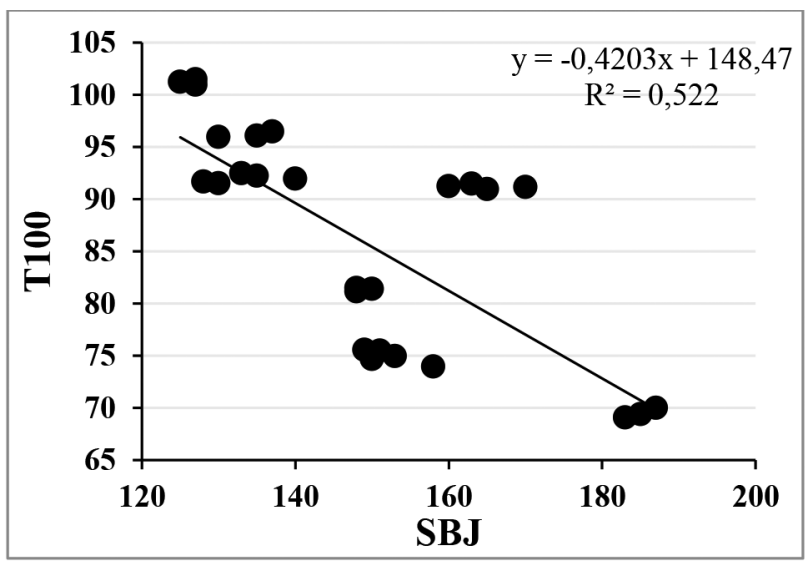

Graph 4. Correlation between the test results of the SBJ test and swim time to $100 \mathrm{~m}$

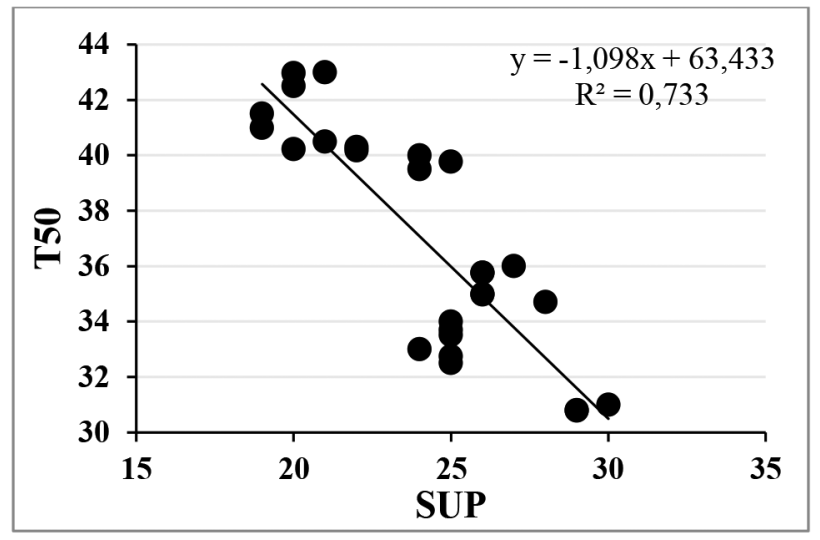

Graph 6. Correlation between the results of the SUP test and swim time to $50 \mathrm{~m}$

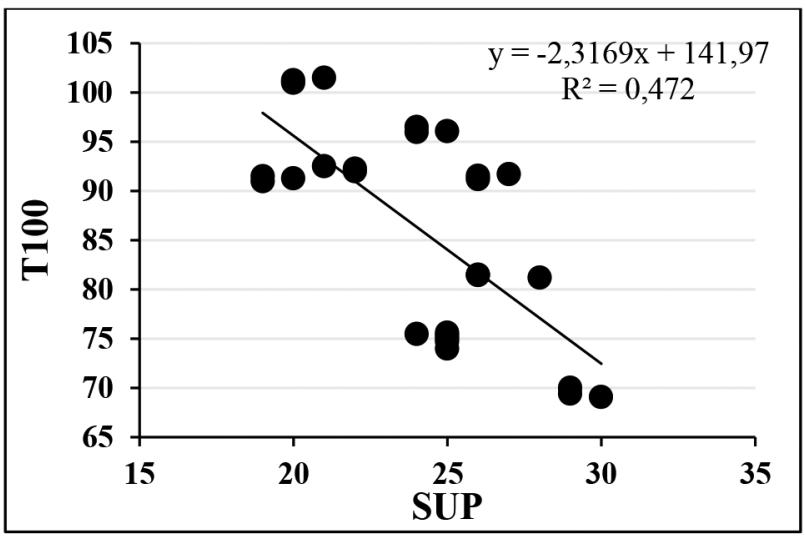

Graph 8. Correlation between the results of the SUP test and swim time to 100 


\section{DISCUSSION}

In this study, on a sample of 27 young swimmers, it was studied the correlation between the test results for strength and power from the Eurofit battery and swim speed at short distances. Based on the obtained results it can be concluded that the tests of power and strength from the Eurofit battery are suitable for the evaluation of strength and power among young swimmers, that is, administrated tests can be predictors of swim speed among young swimmers.

Table 1 shows the descriptive indicators of time and swim speed for the 50 and $100 \mathrm{~m}$ front-crawl as well as the tests results for the strength and power of young swimmers. This group of participants are especially homogenous when it came to swim time and average swim speed, which is an expected result considering that we are dealing with swimmers who had 3 years of training experiance. Based on the descriptive indicators of the tests results for the strength and power it can be concluded that the greatest homogeneity of the results was obtained for the SBJ test and the lowest for the BAH test. These results were expected considering that this group of participants is involved in swimming, works on developing the strength of the leg extensors, which has great influence on one of the important parts of a race, the start (West, Owen, Cunningham, Cook, \& Kilduff, 2011), and thus manifest great and homogenous results in the case of this particular ability. The pronounced lack of homogeneity in the results for the BAH test is also understandable considering that muscle strength to a great extent depends on body mass, which in this period of growth and development varies (Samson et al., 2000). In addition, isometric strength endurance of the arm muscles and the shoulder belt is an ability which plays an important role in swimming, but coaches do not ascribe a lot of importance to the development of this ability, so it can be assumed that this is one of the reasons for the exceptionally nonhomogenous results for this variable. When this results of nonexperimental investigation are compared with the results of similar studies which were carried out on similar samples, it can be, in generally, concluded that this group of participants are average in terms of swim speed and the measured characteristics of strength and power or their age group (Gajević,
2009; Garrido et al. 2010; Morouco et al. 2011; Toskić, D., Lilić, \& Toskić, L., 2014; 2016).

Results of this study indicate that there is a statistically significant correlation between the tests results for the evaluation of strength and power from Eurofit battery test and speed, that is, swim time for the 50 and $100 \mathrm{~m}$ front-crawl in young swimmers (Graph from 1 to 8 ). This means that participants who have achieved better results for the SBJ and SUP tests will swim the 50 and 100 front-crawl much quicker at a greater average swim speed, that is, the participants who manifest a greater level of explosive power of the extensor muscles of the legs and greater strength and endurance for the flexor muscles of the abdomen achieve better results when swimming shorter distances. These results agree with those of previous studies in the field, whose results speak in favor of the fact that there is a high correlation between dry land muscle strength and power and swimming performances (Sharpet al., 1982; Hawley \& Williams, 1991; Hawley et al. 1992; Bradshaw \& Hoyle, 1993; Geladas et al., 2005; Garrido et al. 2010; Morouco et al. 2011; Garrido et al., 2012; Golaet al., 2014; Peterset al., 2014; Keineret al., 2015; Loturco et al., 2016).

Results obtained in this study are expected. As was previously mentioned, it was proven that efficient start is a part of achieved results, and that start is an important part of the race, that is, success in swimming, especially at short distances. Kinetic and kinematic attribute of start to a great extent depends on muscle strength and power (West et al., 2011) of the leg extensors. Swimmers who manifest greater maximum and relative power, as well as maximum, that is, relative strength over a short period of time (RFD), have a quicker and more efficient start. Thus, there is a logical correlation between swim speed at short distances and the explosive power of the leg extensors among young swimmers. It can be assumed that young swimmers who have greater explosive power of the leg extensors will have a better and more efficient start, which creates the preconditions for the greater initial and thus for calculating the average swim speed at short distances, as well as better overall swim time.

A high correlation between strength and endurance of the torso flexors and speed, that is, swim time for short distances was also expected. It was indicated that the torso flexors play an important role 
in the propulsive leg work (Magnusson, Constantini, McHugh, \& Gleim, 1995). This is especially pronounced at short distances, where it is necessary to perform multiple leg kicks over a shorter period of time. Young swimmers who have greater strength and endurance of the torso flexors, that is, those who can do more seated torso lifts during $30 \mathrm{~s}$ have more intense leg kicks, that is, can swim at greater speed over a short period of time during short-distance races.

The obtained results also indicate the fact that the SBJ test has a higher correlation with swim time and average swim speed at a distance of $100 \mathrm{~m}$, while the SUP has a greater correlation to the swim time and average swim speed at a distance of $50 \mathrm{~m}$. The greater correlation between explosive power of the leg extensors and time, that is, swim time to $100 \mathrm{~m}$ can be explained by the fact that explosive power of the leg extensors at a distance of $100 \mathrm{~m}$ is manifested not only during the start but also the turn. The consequence of a greater correlation between the strength and endurance of the torso flexors and speed, that is, time to $50 \mathrm{~m}$ can be explained with more intense strokes, that is, more intense leg kicks at shorter distances. In addition, the SBJ test has a greater correlation with swim speed, while the SUP test has a greater correlation with swim time to 50 and $100 \mathrm{~m}$.

It has shown that there is no statistically significant correlation between results of the BAH test and variables used to evaluate performance in water. In other words, strength and endurance of the muscles of the arms and shoulder belt is not correlated to the speed and time to 50 and $100 \mathrm{~m}$ among young swimmers. These are inntersting results which demand further analsys because their simplified interpretation coul lead to conclusion that isometric strength

\section{REFERENCES}

1. Adam, C., Klissouras, V., Ravazzolo, M., Renson, R., \& Tuxworth, W. (1988). EUROFIT: European test of physical fitness. Rome: Council of Europe, Committee for the development of sport, 10-70.

2. Bradshaw, A., \& Hoyle, J. (1993). Correlation between sprinting and dryland power. The Journal of Swimming Research, 9, 15-29. and endurance of the arm and shoulder belt muscles does not play an important role in swimming. It can be concluded that swimmers do not to a great extent participate in exercises and activities from this test. This result is similar to those found in a certain number of similar studies, and which speak in favor of the fact that there is no statistically significant correlation between certain tests for the evaluation of strength and power and swim speed (Johnson, Sharp, \& Hendrick, 1993; Crowe, Babington, Tanner, \& Stager, 1999; Dominguez-Castelss \& Arrelano, 2011).

\section{CONCLUSION}

Based on the obtained results it can be concluded that there is a high and statistically significant correlation between chosen test from Eurofit battery and time and swim speed for the 50 and $100 \mathrm{~m}$ frontcrawl among young swimmers. Young swimmers who manifest a greater level of explosive power of the leg extensors and strength and endurance of the torso flexors swim the 50 and $100 \mathrm{~m}$ front-crawl with a greater average swim speed. It can be concluded that the above mentioned strength and power tests from Eurofit baterry are good predictors for of swim speed develoopment at shorter distances and are suitable for use during the training process of young swimmers.

Further studies in this field are necessary, studies which would include a greater sample of swimmers of different techniqies and disciplines so as to be able to confirm the predictive values of dry land measurements and its influence on swimming skills.

3. Crowe, S.E., Babington, J.P., Tanner, D.A., \& Stager, J.M. (1986). The relationship of strength to dryland power, swimming power, and swimming performance. Medicine and Science in Sports and Exercise, 31 (5), 255-260.

4. Deschodt, V.J., Arsac, M.L., \& Rouand, H.A. (1999). Relative contribution of arms and legs in humans to propulsion in $25-\mathrm{m}$ sprint front-crawl 
swimming. European Journal of Applied Physiology and Occupational Physiology, 80 (3), 192-199.

5. Dominguez-Castelss, R. \& Arrelano, R. (2011). Muscular and arm crawl stroke power: evaluating their relationship. Portugal Journal of Sport Science, 11 (2), 203-206.

6. Gajević, A. (2009). Fizička razvijenost i fizičke sposobnosti dece osnovnoškolskog uzrasta. Beograd: Republički zavod za sport.

7. Garrido, N. D., Silva, A. J., Fernandes, R. J., Barbosa, T. M., Costa, A. M., Marinho, D., \& Marques, M. C. (2012). High level swimming performance and its relation to non-specific parameters: a cross-sectional study on maximum handgrip isometric strength. Perceptual and Motor Skills, 114 (3), 936-948.

8. Garrido, N., Marinho, A.D., Barbosa, M.T., Costa, M.A., Silva, J.A., Perez-Turpin, A.J., \& Marques, C.M. (2010). Relationship between dry land strength, power variables and short sprint performance in young competitive swimmers. Journal of Human Sport and Exercise, 5 (10), 240-249.

9. Geladas, N. D., Nassis, G. P., \& Pavlicevic, S. (2005). Somatic and physical traits affecting sprint swimming performance in young swimmers. International Journal of Sports Medicine, 26 (02), 139-144.

10. Gola, R., Urbanik, C., Iwanska, D., \& Madej, A. (2014). Relationship between muscle strength and front crawl swimming velocity. Human Movement, 15 (2), 110-115.

11. Hair J, Anderson R, Tatham R, Black W. (1998). Multivariate data analysis. 5th ed. New Jersey, USA: Prentice-Hall. Inc.

12. Hawley, J.A., \& Williams, M.M. (1991). Relationship between upper body anaerobic power and freestyle swimming performance. International Journal of Sports Medicine, 12 (1), 1-5.

13. Hawley, J.A., Williams, M.M., Vickovic, M.M., \& Handcock, P.J. (1992). Muscle power predicts freestyle swimming performance. British Journal of Sport Science, 26 (3), 151-155.

14. Jonhson, R.L., Sharp, R.L., \& Hendrick, C.E. (1993). Relationship of swimming power and dryland power to sprint performance: a multiple regression approach. The Journal of Swimming Research, 9, 10-15.
15. Jürimäe, T., Volbekiene, V., Jürimäe, J., \& Tomkinson, G. R. (2007). Changes in Eurofit test performance of Estonian and Lithuanian children and adolescents (1992-2002). Pediatric Fitness (50), 129-142.

16. Keiner, M., Yaghobi, D., Sander, A., Wirth, K., \& Hartmann, H. (2015). The influence of maximal strength performance of upper and lower extremities and trunk muscles on different sprint swim performances in adolescent swimmers. Science \& Sports, 30 (6), 147-154.

17. Loturco, I., Barbosa, A. C., Nocentini, R. K., Pereira, L. A., Kobal, R., Kitamura, K, Abad, C., Figueiredo, P., \& Nakamura, F. Y. (2016). A correlational analysis of tethered swimming, swim sprint performance and dry-land power assessments. International Journal of Sports Medicine, 37 (3), 211-218.

18. Magnusson, S.P., Constantini, N.W., McHugh, M.P., \& Gleim, W.G. (1995). Strength profiles and performance in masters level swimmers. American Journal of Sports Medicine, 23 (5), 626-631.

19. Morouco, P, Neiva, H., Gonzalez-Badillo, J., Garrido, N., Marinho, D., \& Marques, M. (2011). Associations between dry land strength and power measurments with swimming performance in elite athletes: A pilot study. Journal of Human Kinetics, 29, 105-112.

20. Oja, P., \& Tuxworth, B. (Eds.). (1995). Eurofit for adults: Assessment of health-related fitness. Council of Europe.

21. Peters, S.M., Berry, S., \& Koley, S. (2014). Relationship of physical characteristic, power and swimming time in sprint swimmers. Annals of Biological Research, 5 (8), 24-29.

22. Samson, M. M., Meeuwsen, I. B., Crowe, A., Dessens, J. A., Duursma, S. A., \& Verhaar, H. J. (2000). Relationships between physical performance measures, age, height and body weight in healthy adults. Age and Ageing, 29 (3), 235-242.

23. Sharp, L.R., Troup, P.J., \& Costill, L.D. (1982). Relationship between power and sprint freestyle swimming. Medicine and Science in Sports and Exercise, 14 (1), 53-56.

24. Silva, A.J., Costa, A.M., Oliveira, P.M., Reis, V.M., Saavedra, J., Perl, J., Rouboa, A., \& Marinho, D.A. (2007). The use of neural network technology to 
model swimming performance. Journal of Sports Science and Medicine, 6 (1), 117-125

25. Smith, D.J., Norris, R.S., \& Hogg, M.J. (2002). Performance evaluation of swimmers. Sports Medicine, 32 (9), 539-554.

26. Stzala, M., \& Tyka, A. (2009). Physical endurance, somatic indices and swimming technique parameters as determinants of front crawl swimming speed at short distances in young swimmers. Medicina Sportiva, 13 (2), 99-107.

27. Sweine, I.L. (2000). Arm and leg power output in swimmers during simulated swimming. Medicine and Science in Sports and Exercise, 32 (7), 12881292.

28. Toskić, D., Lilić, Lj., \& Toskić, L. (2014). Differences in older pioneer group swimmers motor skills and morphological characteristic in relation to gender. Research in Kinesiology, 42 (2), 128-133.

29. Toskić, D., Lilić, Lj.,\&Toskić, L. (2016). Correlation between morphological characteristics, bio-mechanic characteristics of the stroke and swimming velocity among pubescent swimmers. Research in Kinesiology, 44 (1), 49-53.

30. Toussaint, H.M., Carol, A., Kranenborg, H., \& Truijens, M.J. (2006). Effects of fatigue on stroking characteristics in arms-only $100-\mathrm{m}$ frontcrawl race. Medicine and Science in Sports and Exercise, 38 (9), 1635-1642.

31. Tsigilis, N., Douda, H., \& Tokmakidis, S. P. (2002). Test-retest reliability of the Eurofit test battery administered to university students. Perceptual and Motor Skills, 95 (3), 1295-1300.

32. West, D.J., Owen, N.J., Cunningham, D.J., Cook, C.J., \& Kilduff, L.P. (2011). Strength and power predictors of swimming starts in international sprint swimmers. Jorunal of Strength and Conditioning Research, 24 (4), 950-955.

33. Zampagni, M.L., Casino, D., Benelli, P., Visani, A., Marcacci, M., \& De Vito, G. (2008). Anthropometric and strength variables to predict freestyle performance times in elite master swimmers. Jorunal of Strength and Conditioning Research, 22 (4), 1298-1307.

\title{
RELACIÓN ENTRE LAS PRUEBAS DE POTENCIA Y DE FUERZA Y VELOCIDAD EN NATACIÓN DE CORTAS DISTANCIAS ENTRE LOS JÓVENES NADADORES
}

\begin{abstract}
Extracto
La natación, el deporte cuya esencia es "ser más rápido" en gran medida depende de la expresión de la potencia y la fuerza, sobre todo en cortas distancias. La evaluación de la potencia y la fuerza fuera del agua es la parte muy importante del entrenamiento en la natación. Sin embargo, sacar conclusiones sobre los resultados de medición fuera del agua en relación con los resultados en la natación es problemático teniendo en cuenta que la expresión de potencia y fuerza en el agua es específica en relación con la en seco. El objetivo del presente trabajo es establecer si existe una relación entre los resultados de las pruebas de potencia y de fuerza de la batería de pruebas Eurofit y la velocidad en natación de cortas distancias en los jóvenes nadadores. Sobre la base de los resultados obtenidos podremos establecer si las pruebas de potencia y fuerza de la batería de pruebas Eurofit son convenientes para evaluar la potencia y la fuerza en los jóvenes nadadores, así como también si pueden ser el predictor de la velocidad en natación de cortas distancias en los jóvenes nadadores. La muestra de los examinados estaba compuesta de los 27 nadadores de edad 13 2.1 año. Los resultados del coeficiente de correlación de Pearson y de análisis de regresión indican que existe una alta relación entre las pruebas de salto de longitud (SBJ) y de acostado-sentado (SUP) con la velocidad promedia de natación a la técnica de crol a $50(\mathrm{r}=0.656, \mathrm{p}=.0 .000 ; \mathrm{r}=0.833, \mathrm{p}=0.000$, respectivamente $)$ y $100 \mathrm{~m}(\mathrm{r}=0.746, \mathrm{p}=0.000 ; \mathrm{r}=0.640, \mathrm{p}=$ 0.000 , respectivamente), así como también con el tiempo de natación a $50(\mathrm{r}=-0.623, \mathrm{p}=0.001 ; \mathrm{r}=-0.856, \mathrm{p}=0.000$, respectivamente) y $100 \mathrm{~m}(\mathrm{r}=-0.723, \mathrm{p}=0.000 ; \mathrm{r}=-0.687, \mathrm{p}=0.000$, respectivamente $)$ a la técnica de crol. Entre la prueba de aguante en barra (BAH) y las variables para evaluar la velocidad en natación no existe una relación estadísticamente significante. Se puede concluir que las pruebas de salto de longitud y de acostado-sentado de la batería de pruebas Eurofit son posibles predictores en sacar conclusiones de la velocidad en natación de cortas distancias en los jóvenes nadadores, es decir son convenientes para la aplicación en la selección de jóvenes nadadores.
\end{abstract}

Palabras claves. NATACIÓN / CAPACIDADES MOTRICES / EUROFIT / NIÑOS

Received: 11.10. 2018.

Accepted: 06.12.2018. 


\title{
ПОВЕЗАНОСТ ИЗМЕБУ ТЕСТОВА ЈАЧИНЕ И СНАГЕ И БРЗИНЕ ПЛИВАЫА НА КРАТКИМ ДИСТАНЦАМА КОД МЛАДИХ ПЛИВАЧА
}

\author{
Драган Тоскић \\ Универзитет у Приштини, Факултет за спорт и физичко васпитање, Лепосавић, Србија
}

\begin{abstract}
Сажетак
Пливање, спорт чија је суштина „бити што бржи“, у великој мери зависи од испољавања јачине и снаге, нарочито на кратким дистанцама. Процењивање јачине и снаге ван воде у пливању је важан део тренажног процеса. Међутим, закључивање о резултатима мерења ван воде на резултате у пливању је проблематично с обзиром да је испољавање јачине и снаге у води специфично у односу на сувом. Циљ овог рада је да се утврди да ли постоји повезаност између резултата тестова јачине и снаге из Еурофит батерије тестова и брзине пливања на кратким дистанцама код младих пливача. На основу добијених резултата моћи ћемо да утврдимо да ли су тестови јачине и снаге из Еурофит батерије тестова погодни за процену јачине и снаге код младих пливача, као и да ли могу бити предиктор брзине пливања на кратким дистанцама код младих пливача. Узорак испитаника је чинило 27 пливача узраста $13 \pm 2.1$ године. Резултати Пирсоновог коефицијента корелације и регресионе анализе указују да постоји висока повезаност између тестова скок у даљ (СБЈ) и лежање - сед (СУП) са средњом брзином пливања краул техником на $50(\mathrm{r}=0.656, \mathrm{p}=0.000 ; \mathrm{r}=0.833, \mathrm{p}=0.000$, респективно $)$ и $100 \mathrm{м}(\mathrm{r}=0.746, \mathrm{p}=0.000 ; \mathrm{r}=0.640, \mathrm{p}=0.000$, респективно), као и временом пливања на $50(\mathrm{r}=-0.623, \mathrm{p}=0.001 ; \mathrm{r}=-0.856, \mathrm{p}=0.000$, респективно $)$ и $100 \mathrm{м}(\mathrm{r}=-0.723, \mathrm{p}=0.000 ; \mathrm{r}=-0.687, \mathrm{p}=$ 0.000 , респективно) краул техником. Између теста издржај у згибу (БАХ) и варијабли за процену брзине пливања не постоји статистички значајна повезаност. Може се закључити да су тестови скок у даљ и лежање - сед из Еурофит батерије тестова могући предиктори у закључивању о брзини пливања на кратким дистанцама код младих пливача, односно погодни су за примену у селекцији младих пливача.
\end{abstract}

Кључне речи: ПЛИВАҢЕ / МОТОРИЧКЕ СПОСОБНОСТИ / ЕУРОФИТ / ДЕЦА

\section{УВОД}

Јачина и снага играју важну улогу у већини спортова, па тако и у пливању. Пливање, као спорт чија је суштина бити бржи, у великој мери зависи од испољавања јачине, односно снаге (Sharp, Troup, \& Costill, 1982; Garrido et al., 2010; Morouco et al., 2011). Ово је нарочито изражено на кратким дистанцама, где експлозивна и максимална јачина и снага играју одлучујућу улогу (Hawley \& Williams, 1991; Strzala \& Tyka, 2009; Garrido et al., 2010; Morouco et al., 2011).

Процењивањејачинеи снагеван водеупливању је саставни део тренажног процеса (Smith, Norris, $\&$ Hogg, 2002). Подаци о испољеној јачини и снази могу дати увид у то да ли је тренинг јачине и снаге био ефикасан, као и да ли је тренинг био усмерен на оне способности које доводе до повећања перформанси у пливању. Процена јачине и снаге ван воде може пружити увид у повезаност између одређених карактеристика јачине, снаге и брзине пливања, односно предиктивних вредности одређених тестова за процену јачине и снаге, што може играти важну улогу у селекцији (Zampagni et al., 2008). Међутим, закључивање након мерења јачине и снаге ван воде на резултате у пливању је проблематично, с обзиром да је кретање у води специфично у односу на кретање ван воде (Swaine, 2000; Smith et al. 2002). 
Бројна истраживања су испитивала повезаност карактеристика јачине и снаге мерених ван воде и перформанси испољених у води. Резултати великог броја истраживања указују на то да постоји висока повезаност између карактеристика јачине и снаге мерених на сувом и брзине пливања на кратким дистанцама, како код старијих (Sharp et al., 1982; Hawley \& Williams, 1991; Hawley, Williams, Vickovic, \& Handcock, 1992; Bradshaw \& Hoyle, 1993; Gola, Urbanik, Iwanska, \& Madej, 2014; Peters, Berry, \& Koley, 2014; Loturco et al., 2016) тако и код младих пливача (Geladas, Nassis, \& Pavlicevic, 2005; Garrido et al., 2010; Morouco et al., 2011; Garrido et al., 2012; Keiner, Yaghobi, Sander, Wirth, \& Hartmann, 2015). Међутим, одређена истраживања негирају повезаност карактеристика јачине и снаге мерених ван воде и пливачких перформанси, што указује на опрезност (Johnson, Sharp, \& Hendrick, 1993; Crowe, Babington, Tanner, \& Stager, 1999; Dominguez-Castelss \& Arrelano, 2011).

Добијене разлике у резултатима истраживања се могу приписати објективности самих тестова али и мерним инструментима. Као што је поменуто, пливање је специфичан спорт, где се испољавање јачине и снаге у води у значајној мери разликује од испољавања јачине и снаге на тлу. Самим тим, нису сви мерни инструменти погодни за испитивање повезаности јачине и снаге ван воде и перформанси испољених у води. Тестови за процену јачине и снаге у пливању би требало бити такви, да кретање приликом извршења задатка не одступа драстично од специфичног кретања у води (Smith et al., 2002). Али, мерни инструменти за овакву врсту процене су скупи и врло често недоступни тренерима и стручњацима који раде у пливању. Нарочито је то проблем код рада са младим пливачима. Одређени аутори указују на чињеницу да код младих пливача није потребна скупа и компликована опрема за процену јачине и снаге на сувом која одузима пуно времена (Silva et al., 2007). Такође, један од недостатака претходних истраживања је то што се највећи број истраживања ограничио на процењивање јачине и снаге мишића руку и раменог појаса, иако мишићи ногу, трбушног зида и леђа играју значајну улогу у пливању (Deschodt et al., 1999; Toussaint et al., 2006; Keiner et al., 2015).

Мали је број истраживања која су се бавила испитивањем повезаности тестова јачине и снаге из Еурофит батерије тестова и брзине пливања. Еурофит батерија тестова је широко употребљивана батерија тестова која је једноставна за употребу, поуздана за процену моторичких способности. Резултати тих тестова се могу упоредити са резултатима тестова испитаника истог узраста из целе Европе, и што је најбитније доступна је за коришћење и не изискује скупу опрему, што је веома важно, нарочито стручњацима који раде са децом (Oja \& Tuxworth, 1995; Tsigilis, Douda, \& Tokmakidis, 2002; Gajević, 2009).

Проблем овог рада представља процена јачине и снаге ван воде код младих пливача. Циљ рада је да се утврди да ли постоји повезаност између резултата тестова јачине и снаге из Еурофит батерије тестова и брзине пливања на кратким дистанцама код младих пливача. На основу добијених резултата моћи ће да се утврди да ли су тестови јачине и снаге из Еурофит батерије погодни за процену јачине и снаге код младих пливача, односно да ли могу бити предиктор брзине пливања код младих пливача. Претпоставља се да ће одређени тестови показати високу повезаност са брзином пливања код младих пливача.

\section{МЕТОД РАДА}

\section{Узорак испитаника}

Узорак испитаника је чинило 27 пливача и то 15 дечака и 12 девојчица (узраст: $13 \pm 2.1$ године, тв $=156.1$ цм, тм = 47.3 кг, бми $\left.=18.9 \kappa г / \mathrm{M}^{2}\right)$. Сви испитаници су активни пливачи, тренирају пливање најмање 3 године и активно се такмиче у својим узрасним категоријама. Испитаници и њихови родитељи су упознати са сврхом и циљем истраживања и добровољно су пристали на учешће у истраживању. Сва тестирања су спроведена у складу са правилима Хелсиншке декларације и Етичког комитета Факултета за спорт и физичко васпитање Универзитета у Приштини.

\section{Узорак варијабли}

Узорак варијабли су чиниле 4 варијабле за процену брзине пливања краул техником и 3 
варијабле за процену мишићне јачине и снаге. Варијабле које процењују брзину пливања су (Geladas et al., 2005; Toskić, D., Lilić, \& Toskić, L., 2016):

- време пливања на 50 м (т50)

- средња брзина пливања на 50 м (v50)

- време пливања на 100 м (т100)

- средња брзина пливања на 100 м (v100)

Брзина пливања на 50 м је израчуната тако што се испливана дужина дистанце, без дужине скока, подели са временом потребним да се та дистанца исплива, док је за брзину пливања на 100 м урачуната и дужина, односно време окрета. Пливачки тестови су снимани камером. Дужина старта и окрета је одређивана као растојање које пливач пређе од ивице базена до тачке када рука изађе на површину воде након подводног завеслаја.

Варијабле за процену јачине и снаге су:

- скок у даљ (СБЈ) - за процену експлозивне снаге мишића опружача ногу

- лежање - сед (СУП) - за процену издржљивости у снази мишића прегибача трупа

- издржај у згибу (БАХ) - за процену издржљивости у јачини мишића руку и раменог појаса.

Тестови за процену јачине и снаге примењени у овом истраживању су преузети из Еурофит батерије тестова (Council of Europe, 1988; Kemper \& Van Mechelen, 1996; Jürimäe, Volbekiene, Jürimäe, \& Tomkinson, 2007). Разлог за одабир ових варијабли, као и за одабир Еурофит батерије тестова је у доступности и једноставности. Као што је раније напоменуто, сигурно је да постоје прецизнији инструменти за процењивање горе споменутих способности, међутим ти инструменти су често врло скупи и недоступни пливачким тренерима који раде са децом. Изабрани су тестови који не изискују скупу опрему, једноставни су за примену, валидни за процењивање одређених способности и резултати у тим мерењима се могу упоредити са резултатима других испитаника истог узраста из целе Европе.

\section{Процедура мерења}

Сва мерења су извршена у истим условима. Испитаници су били здрави, одморни и сва тестирања су извршена у јутарњим часовима.
Тестирањима је претходило загревање како не би дошло до повреде и како би били у стању да испоље оптималне способности у води и ван ње. Време и средња брзина пливања су мерени у базену дужине 50 м, док су јачина и снага мерени у помоћним просторијама пливалишта. Испитаници су краул техником испливавали 50 (т50; v50) и 100 м (т100; v100) максималном брзином, у два различита дана. Тестирање мишићне јачине и снаге се вршило према правилима и процедурама мерења Еурофит батерије тестова. Мерења брзине, односно времена пливања и мерења јачине и снаге су извршена у различитим данима како би испитаници били у стању да се одморе. Сва мерења су извршена од стране истих искусних мерилаца.

\section{Статистичка обрада података}

У овом раду је примењена дескриптивна статистичка процедура (Mean, SD, cV\%, Min, Max), израчунат је Пирсонов коефицијент корелације и примењена линеарна регресиона анализа. Дескриптивна статистика је примењена како би се описале мерене варијабле, док су Пирсонов коефицијент корелације и регресиона анализа примењени како би се утврдила повезаност и карактер повезаности између мерених варијабли. Статистичка значајност је израчуната на нивоу од $95 \%$; п 0.05 (Hair et al., 1998), док су све статистичке процедуре спроведене у програму СПСС 19 (IBM).

\section{РЕЗУЛТАТИ}

На табели 1 су приказани дескриптивни показатељи времена и брзине пливања на 50 и 100 м краул техником као и резултата тестова јачине и снаге код младих пливача. Као што се може видети испитаници имају просечно време пливања на 50 м краул техником 36.8 с и просечну брзину пливања од $1.46 \mathrm{~m} / \mathrm{c}$, док просечно време пливања на 100 м износи 85.9 с при просечној брзини пливања од 0.56 м/с. Према показатељима хомогености резултата (cV \%), може се закључити да су испитаници били хомогени када су у питању ове варијабле. Када су у питању резултати тестова за процену јачине и снаге може се закључити да 
је просечни резултат скока у даљ код ове групе испитаника 148.7 цм, просечан број подизања трупа је 24.1 за 30 секунди, и испитаници су имали просечан резултат од 16.2 с када је у питању тест издржај у згибу. На основу показатеља хомогености резултата, може се закључити да су испитаници најхомогенији када је у питању варијабла СБЈ (cV = $12.2 \%$ ), док су најмање хомогени у варијабли БАХ $(\mathrm{cV}=44.6 \%)$.

Табела 1. Дескриптивни показатељи времена и

брзине пливања на 50 и 100м краулом и резултати на тестовима јачине и снаге

\begin{tabular}{cccccccc}
\hline & $\begin{array}{c}\mathbf{T 5 0} \\
(\mathbf{s})\end{array}$ & $\begin{array}{c}\mathbf{v 5 0} \\
(\mathbf{m} / \mathbf{s})\end{array}$ & $\begin{array}{c}\mathbf{T 1 0 0} \\
(\mathbf{s})\end{array}$ & $\begin{array}{c}\mathbf{v 1 0 0} \\
(\mathbf{m} / \mathbf{s})\end{array}$ & $\begin{array}{c}\text { CБJ } \\
(\mathbf{c m})\end{array}$ & $\begin{array}{c}\text { CУП } \\
(\mathbf{m} / \mathbf{3 0 s})\end{array}$ & $\begin{array}{c}\text { 5AX } \\
(\mathbf{s})\end{array}$ \\
\hline Mean & 36.8 & 1.46 & 85.9 & 0.56 & 148.7 & 24.1 & 16.2 \\
SD & 4.02 & 0.18 & 10.5 & 0.08 & 18.1 & 3.1 & 7.2 \\
cV\% & 10.9 & 12.5 & 12.3 & 14.4 & 12.2 & 12.9 & 44.6 \\
Min & 30.7 & 1.18 & 69.1 & 0.43 & 125.2 & 19 & 8 \\
Max & 43.1 & 1.87 & 101.5 & 0.74 & 186 & 30 & 30.2 \\
\hline
\end{tabular}

На графиконима од 1 до 8 су приказане статистички значајне корелације између резултата тестова за процену јачине и снаге, и брзине односно времена пливања на 50 и 100 м краул техником. Може се закључити да постоји висока и статистички значајна корелација између варијабли СБЈ, средње брзине пливања на $50(\mathrm{r}=0.656, \mathrm{p}=0.000)$ и 100 м $(\mathrm{r}=0.746, \mathrm{p}=0.000)$ као и времена пливања на $50(\mathrm{r}=-0.623, \mathrm{p}=0.001)$ и 100 м $(\mathrm{r}=-0.723, \mathrm{p}=$ 0.000). Варијабла СУП има високу и статистички значајну повезаност са брзином пливања на 50 (r $=0.833, \mathrm{p}=0.000)$ и 100 м $(\mathrm{r}=0.640, \mathrm{p}=0.000)$, као и са временом пливања на 50 ( $\mathrm{r}=-0.856$, $\mathrm{p}=0.000)$ и 100 м $(\mathrm{r}=-0.687, \mathrm{p}=0.000)$. Тест БАХ нема статистички значајну повезаност са варијаблама које процењују брзину пливања на 50 и 100 м.

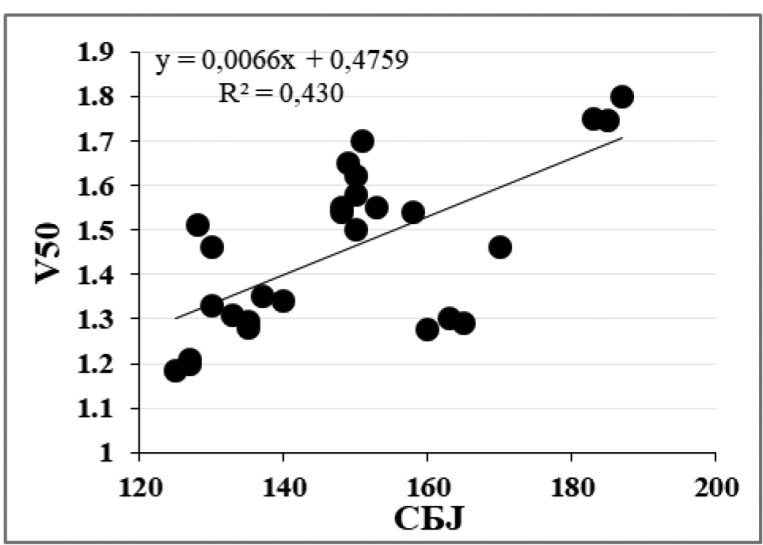

График 1. Повезаност резултата мерења СБЈ и брзине пливања $50 \mathrm{M}$

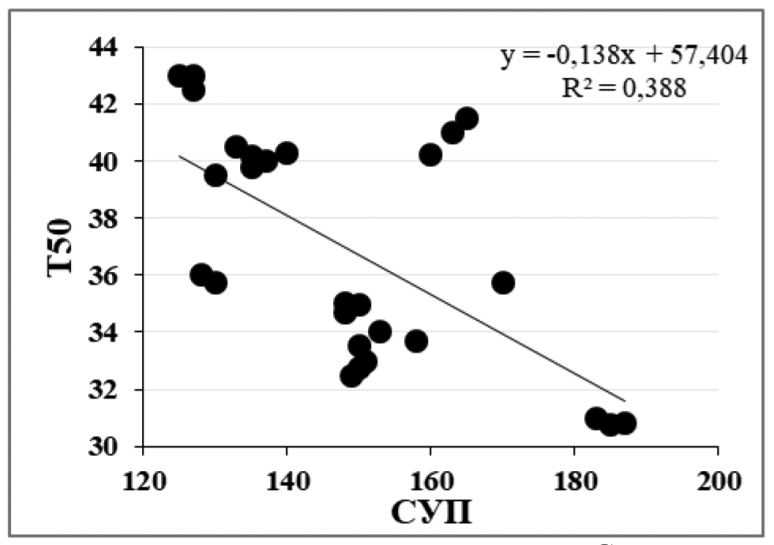

График 2. Повезаност резултата мерења СУП и времена пливања 50м 


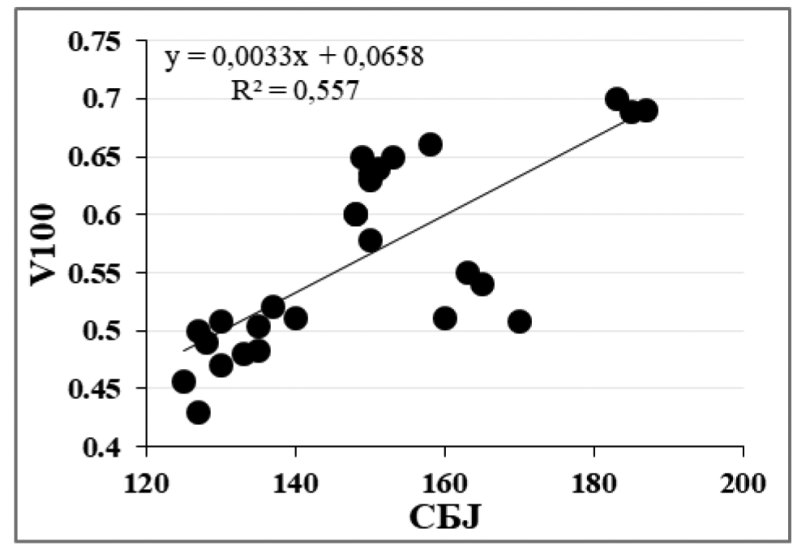

График 3. Повезаност резултата мерења СБЈ и брзина пливања $100 \mathrm{M}$

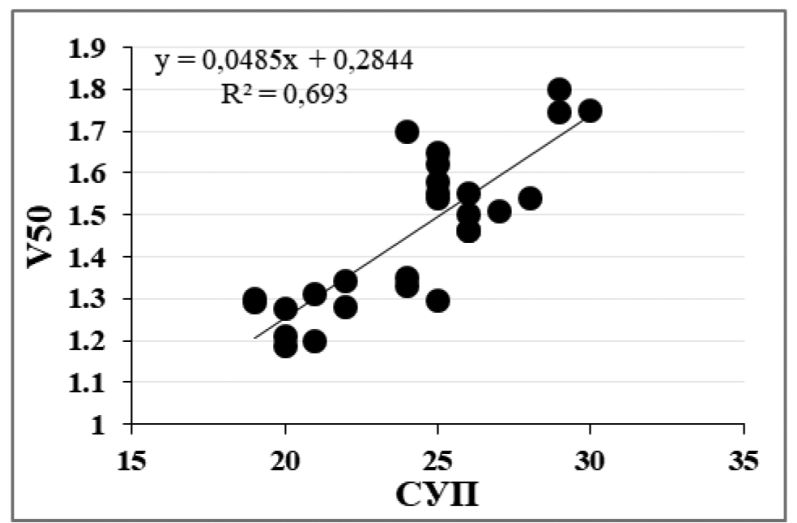

График 5. Повезаност резултата мерења СУП и брзине пливања 50м

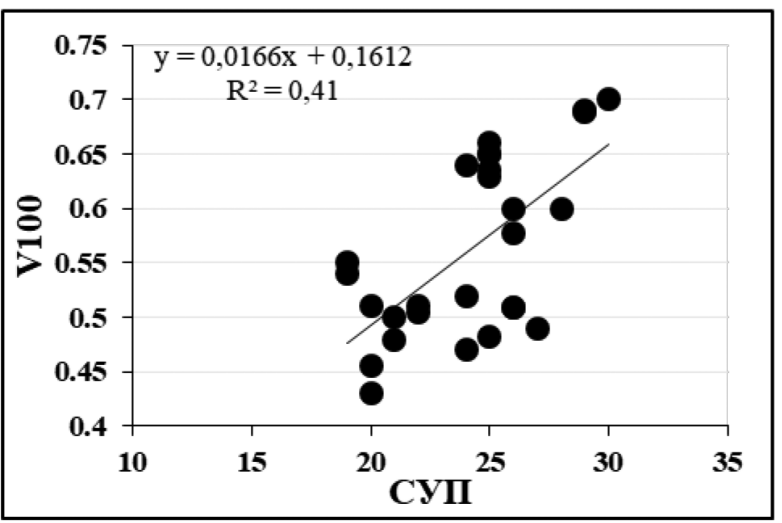

График 7. Повезаност резултата мерења СУП и брзине пливања $100 \mathrm{M}$

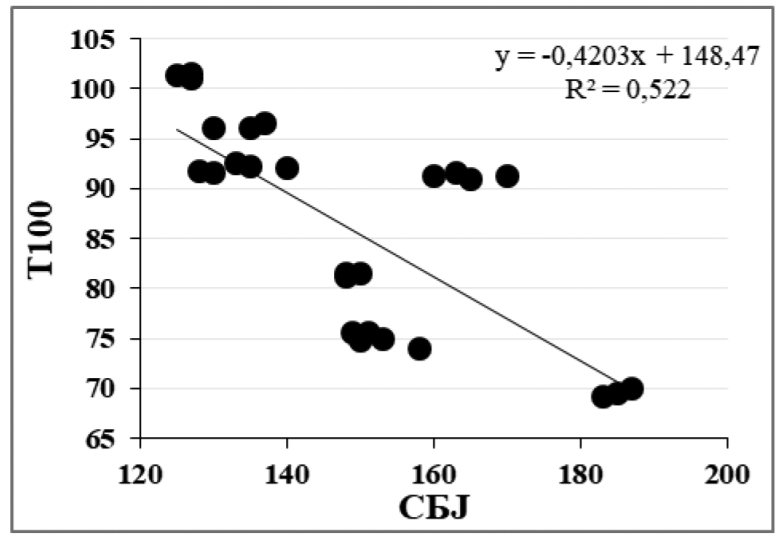

График 4. Повезаност резултата мерења СБЈ и времена пливања 100м

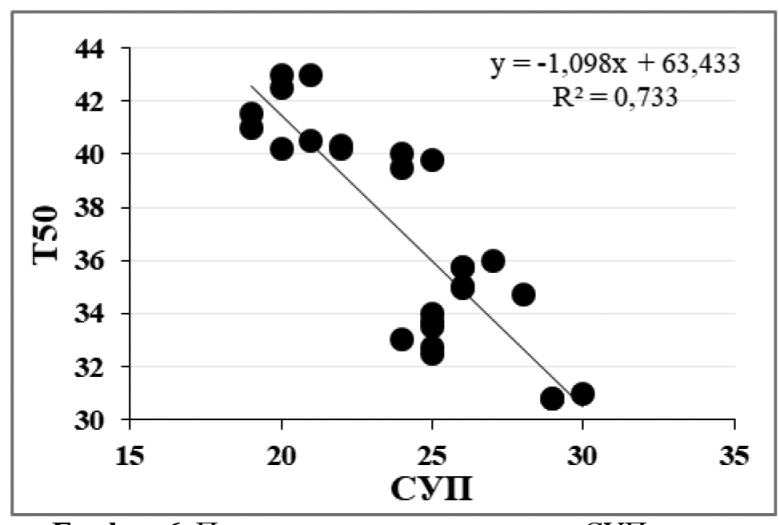

График 6. Повезаност резултата мерења СУП и времена пливања 50м

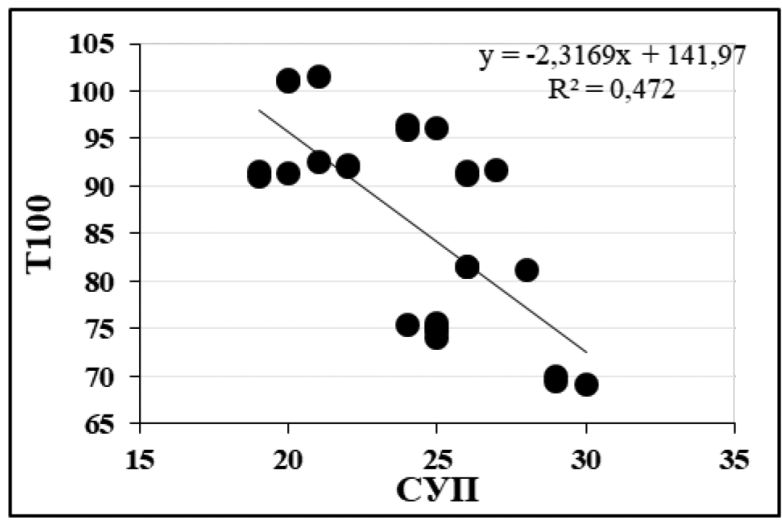

График 8. Повезаност резултата мерења СУП и времена пливања $100 \mathrm{M}$ 


\section{ДИСКУСИЈА}

У овом истраживању, на узорку од 27 младих пливача, испитивана је повезаност између резултата тестова јачине и снаге из Еурофит батерије и брзине пливања на кратким дистанцама код младих пливача. На основу добијених резултата утврђено је да су тестови јачине и снаге из Еурофит батерије погодни за процену јачине и снаге код младих пливача, односно да администрирани тестови могу бити предиктор брзине пливања код младих пливача.

У табели 1 су приказани дескриптивни показатељи времена и брзине пливања на 50 и 100 м краул техником као и резултати тестова јачине и снаге код младих пливача. Испитаници су изузетно хомогени када су у питању време и средња брзина пливања. То је очекиван резултат, с обзиром да се ради о пливачима са три године тренажног стажа. На основу дескриптивних показатеља резултата тестова јачине и снаге може се закључити да је највећа хомогеност резултата добијена код теста СБЈ, а најмања код теста БАХ. Ови резултати су очекивани, с обзиром да се ова група испитаника бави пливањем, „раде“ на развоју снаге мишића опружача ногу за коју се показало да има велики утицај на старт који је важан део сваке трке (West, Owen, Cunningham, Cook, \& Kilduff, 2011). Самим тим испољавају велике и уједначене резултате када је у питању ова способност. Изражена нехомогеност резултата код теста БАХ је такође разумљива с обзиром да мишићна јачина у великој мери зависи од телесне масе, која у овом периоду раста и развоја варира (Samson et al., 2000). Такође, издржљивост у јачини мишића руку и раменог појаса је способност која игра важну улогу у пливању, али тренери не придају много значаја на развој ове способности, па се може претпоставити да је и то један од разлога изузетно нехомогених резултата у овој варијабли. Када се упореде резултати овог неексперименталног посматрања са резултатима сличних истраживања која су спроведена на сличном узорку, може се, генерално гледано закључити, да ова група испитаника спада у групу просечних у погледу брзине пливања и мерених карактеристика јачине и снаге за њихов узраст (Gajević, 2009; Garrido et al. 2010; Morouco et al. 2011; Toskić, D., Lilić, \& Toskić, L., 2014; 2016).
Резултати ове студије указују да постоји статистички значајна повезаност између резултата тестова за процену јачине и снаге из Еурофит батерије тестова и брзине, односно времена пливања краул техником на 50 и 100 м код младих пливача (Графикони од 1 до 8). То значи да испитаници који су постигли боље резултате у тестовима СБЈ и СУП пливају 50 и 100 м краул техником за краће време при већој средњој брзини пливања, односно испитаници који испољавају већи ниво експлозивне снаге мишића опружача ногу и већу издржљивост у снази мишића прегибача трупа постижу боље резултате у пливању на кратким дистанцама. Ови резултати су у складу са претходним истраживањима из ове области, где резултати иду у прилог чињеници да постоји висока повезаност између мишићне јачине и снаге мерених на сувом и пливачких перформанси (Sharpet al., 1982; Hawley \& Williams, 1991; Hawley et al. 1992; Bradshaw \& Hoyle, 1993; Geladas et al., 2005; Garrido et al. 2010; Morouco et al. 2011; Garrido et al., 2012; Golaet al., 2014; Peterset al., 2014; Keineret al., 2015; Loturco et al., 2016).

Резултати добијени у овом истраживању су очекивани. Као што је претходно напоменуто, показало се да се унутар постигнутих резултата налазе и ефекти старта, који је важан део трке, односно успеха у пливању, нарочито на кратким дистанцама. Кинематички и кинетички атрибути старта, у великој мери зависе од снаге, односно јачине мишића опружача ногу (West et al., 2011). Пливачи који испољавају већу максималну и релативну снагу, као и максималну, односно релативну јачину, нарочито за кратко време (РФД), имају бржи и ефикаснији старт. Самим тим је логична повезаност између брзине, односно времена пливања на кратким дистанцама и експлозивне снаге мишића опружача ногу код младих пливача. Може се претпоставити да млади пливачи који имају већу експлозивну снагу мишића опружача ногу имају бољи и ефикаснији старт, чиме се стварају предуслови за већу почетну, а самим тим и за израчунавање просечне брзине пливања на кратким дистанцама, као и боље крајње време пливања.

Висока повезаност између издржљивости у снази мишића прегибача трупа и брзине, односно времена пливања на кратким дистанцама је такође очекивана. Показало се да прегибачи мишића трупа играју важну улогу у пропулзивном раду 
ногу (Magnusson, Constantini, McHugh, \& Gleim, 1995). Ово је нарочито изражено на кратким дистанцама, где је за кратко време неопходно урадити више интензивних удараца ногама. Млади пливачи који имају већу издржљивост у снази мишића прегибача трупа, односно који за 30 секунди могу да ураде више подизања трупа из лежећег положаја, имају интензивније ударце ногама, односно на кратким дистанцама могу да пливају већом брзином.

Добијени резултати такође указују на чињеницу да тест СБЈ има већу повезаност са временом и средњом брзином пливања на 100 м, док СУП има већу повезаност са временом и средњом брзином пливања на 50 м. Већа повезаност експлозивне снаге мишића опружача ногу са временом, односно брзином пливања на 100 м се може објаснити чињеницом да се експлозивна снага мишића опружача ногу на 100 м испољава не само при старту, већ и при окрету. Последица веће повезаности издржљивости у снази мишића прегибача трупа и брзине, односно времена на 50 м се може објаснити интензивнијим завеслајима, односно интензивнијим радом ногу на краћим дистанцама. Такође, тест СБЈ има већу повезаност са брзином пливања, док тест СУП има већу повезаност са временом пливања на 50 и 100 м.

Нијеутврђенастатистичкизначајнаповезаност између резултата на тесту БАХ са варијаблом која процењује перформансе у води. Другим речима, издржљивост у јачини мишића руку и раменог појаса нема повезаност са брзином и временом пливања на 50 и 100 м краул техником код младих пливача. Ово су интересантни резултати који захтевају даљу анализу, јер би њихово једноставно тумачење могло да доведе до закључка да

\section{ЛИТЕРАТУРА}

1. Adam, C., Klissouras, V., Ravazzolo, M., Renson, R., \& Tuxworth, W. (1988). EUROFIT: European test of physical fitness. Rome: Council of Europe, Committee for the development of sport, 10-70.

2. Bradshaw, A., \& Hoyle, J. (1993). Correlation between sprinting and dryland power. The Journal of Swimming Research, 9, 15-29.

3. Crowe, S.E., Babington, J.P., Tanner, D.A., \& Stager, J.M. (1986). The relationship of strength to издржљивост у јачини мишића руку и раменог појаса не игра важну улогу у пливању. Закључак је и тај да пливачи не упражњавају у великој мери вежбе и активности, како је то предвиђено овим тестом. Овај закључак је сличан резултатима код одређеног броја истраживања која су се бавила овом тематиком, а која говоре у прилог чињеници да не постоји статистички значајна повезаност између одређених тестова за процену јачине, односно снаге и брзине пливања (Johnson, Sharp, \& Hendrick, 1993; Crowe, Babington, Tanner, \& Stager, 1999; Dominguez-Castelss \& Arrelano, 2011).

\section{ЗАКЉУЧАК}

На основу добијених резултата може се увидети да постоји висока и статистички значајна повезаност између одабраних тестова Еурофит батерије са временом и брзином пливања на 50 и 100 м краул техником код младих пливача. Млади пливачи који испољавају већи ниво експлозивне снаге мишића опружача ногу и издржљивости у снази мишића прегибача трупа пливају 50 и 100 м краул техником већом средњом брзином. Може се закључити да су поменути тестови добри предиктори за изградњу брзине пливања на кратким дистанцама и погодно их је користити у тренингу младих пливача.

Неопходна су даља истраживања из ове области, са већим узорком пливача различитих пливачких техника и дисциплина како би са већом сигурношћу могли да се потврде предиктивне вредности мерења ван воде на способности и вештину пливања. dryland power, swimming power, and swimming performance. Medicine and Science in Sports and Exercise, 31 (5), 255-260.

4. Deschodt, V.J., Arsac, M.L., \& Rouand, H.A. (1999). Relative contribution of arms and legs in humans to propulsion in 25-m sprint front-crawl swimming. European Journal of Applied Physiology and Occupational Physiology, 80 (3), 192-199. 
5. Dominguez-Castelss, R. \& Arrelano, R. (2011). Muscular and arm crawl stroke power: evaluating their relationship. Portugal Journal of Sport Science, 11 (2), 203-206.

6. Gajević, A. (2009). Fizička razvijenost i fizičke sposobnosti dece osnovnoškolskog uzrasta. Beograd: Republički zavod za sport.

7. Garrido, N. D., Silva, A. J., Fernandes, R. J., Barbosa, T. M., Costa, A. M., Marinho, D., \& Marques, M. C. (2012). High level swimming performance and its relation to non-specific parameters: a cross-sectional study on maximum handgrip isometric strength. Perceptual and Motor Skills, 114 (3), 936-948.

8. Garrido, N., Marinho, A.D., Barbosa, M.T., Costa, M.A., Silva, J.A., Perez-Turpin, A.J., \& Marques, C.M. (2010). Relationship between dry land strength, power variables and short sprint performance in young competitive swimmers. Journal of Human Sport and Exercise, 5 (10), 240-249.

9. Geladas, N. D., Nassis, G. P., \& Pavlicevic, S. (2005). Somatic and physical traits affecting sprint swimming performance in young swimmers. International Journal of Sports Medicine, 26 (02), 139-144.

10. Gola, R., Urbanik, C., Iwanska, D., \& Madej, A. (2014). Relationship between muscle strength and front crawl swimming velocity. Human Movement, 15 (2), 110-115.

11. Hair J, Anderson R, Tatham R, Black W. (1998). Multivariate data analysis. 5th ed. New Jersey, USA: Prentice-Hall. Inc.

12. Hawley, J.A., \& Williams, M.M. (1991). Relationship between upper body anaerobic power and freestyle swimming performance. International Journal of Sports Medicine, 12 (1), 1-5.

13. Hawley, J.A., Williams, M.M., Vickovic, M.M., \& Handcock, P.J. (1992). Muscle power predicts freestyle swimming performance. British Journal of Sport Science, 26 (3), 151-155.

14. Jonhson, R.L., Sharp, R.L., \& Hendrick, C.E. (1993). Relationship of swimming power and dryland power to sprint performance: a multiple regression approach. The Journal of Swimming Research, 9, 10-15.

15. Jürimäe, T., Volbekiene, V., Jürimäe, J., \& Tomkinson, G. R. (2007). Changes in Eurofit test performance of Estonian and Lithuanian children and adolescents (1992-2002). Pediatric Fitness (50), 129-142.

16. Keiner, M., Yaghobi, D., Sander, A., Wirth, K., \& Hartmann, H. (2015). The influence of maximal strength performance of upper and lower extremities and trunk muscles on different sprint swim performances in adolescent swimmers. Science \& Sports, 30 (6), 147-154.

17. Loturco, I., Barbosa, A. C., Nocentini, R. K., Pereira, L. A., Kobal, R., Kitamura, K, Abad, C., Figueiredo, P., \& Nakamura, F. Y. (2016). A correlational analysis of tethered swimming, swim sprint performance and dry-land power assessments. International Journal of Sports Medicine, 37 (3), 211-218.

18. Magnusson, S.P., Constantini, N.W., McHugh, M.P., \& Gleim, W.G. (1995). Strength profiles and performance in masters level swimmers. American Journal of Sports Medicine, 23 (5), 626-631.

19. Morouco, P, Neiva, H., Gonzalez-Badillo, J., Garrido, N., Marinho, D., \& Marques, M. (2011). Associations between dry land strength and power measurments with swimming performance in elite athletes: A pilot study. Journal of Human Kinetics, 29, 105-112.

20. Oja, P., \& Tuxworth, B. (Eds.). (1995). Eurofit for adults: Assessment of health-related fitness. Council of Europe.

21. Peters, S.M., Berry, S., \& Koley, S. (2014). Relationship of physical characteristic, power and swimming time in sprint swimmers. Annals of Biological Research, 5 (8), 24-29.

22. Samson, M. M., Meeuwsen, I. B., Crowe, A., Dessens, J. A., Duursma, S. A., \& Verhaar, H. J. (2000). Relationships between physical performance measures, age, height and body weight in healthy adults. Age and Ageing, 29 (3), 235-242.

23. Sharp, L.R., Troup, P.J., \& Costill, L.D. (1982). Relationship between power and sprint freestyle swimming. Medicine and Science in Sports and Exercise, 14 (1), 53-56.

24. Silva, A.J., Costa, A.M., Oliveira, P.M., Reis, V.M., Saavedra, J., Perl, J., Rouboa, A., \& Marinho, D.A. (2007). The use of neural network technology to model swimming performance. Journal of Sports Science and Medicine, 6 (1), 117-125 
25. Smith, D.J., Norris, R.S., \& Hogg, M.J. (2002). Performance evaluation of swimmers. Sports Medicine, 32 (9), 539-554.

26. Stzala, M., \& Tyka, A. (2009). Physical endurance, somatic indices and swimming technique parameters as determinants of front crawl swimming speed at short distances in young swimmers. Medicina Sportiva, 13 (2), 99-107.

27. Sweine, I.L. (2000). Arm and leg power output in swimmers during simulated swimming. Medicine and Science in Sports and Exercise, 32 (7), 12881292.

28. Toskić, D., Lilić, Lj., \& Toskić, L. (2014). Differences in older pioneer group swimmers motor skills and morphological characteristic in relation to gender. Research in Kinesiology, 42 (2), 128-133.

29. Toskić, D., Lilić, Lj.,\&Toskić, L. (2016). Correlation between morphological characteristics, bio-mechanic characteristics of the stroke and swimming velocity among pubescent swimmers. Research in Kinesiology, 44 (1), 49-53.
30. Toussaint, H.M., Carol, A., Kranenborg, H., \& Truijens, M.J. (2006). Effects of fatigue on stroking characteristics in arms-only $100-\mathrm{m}$ frontcrawl race. Medicine and Science in Sports and Exercise, 38 (9), 1635-1642.

31. Tsigilis, N., Douda, H., \& Tokmakidis, S. P. (2002). Test-retest reliability of the Eurofit test battery administered to university students. Perceptual and Motor Skills, 95 (3), 1295-1300.

32. West, D.J., Owen, N.J., Cunningham, D.J., Cook, C.J., \& Kilduff, L.P. (2011). Strength and power predictors of swimming starts in international sprint swimmers. Jorunal of Strength and Conditioning Research, 24 (4), 950-955.

33. Zampagni, M.L., Casino, D., Benelli, P., Visani, A., Marcacci, M., \& De Vito, G. (2008). Anthropometric and strength variables to predict freestyle performance times in elite master swimmers. Jorunal of Strength and Conditioning Research, 22 (4), 1298-1307.

Примљен: 11.10. 2018. Прихваћен: 06. 12. 2018. 